\title{
Nutritional Characteristics of Teak Grasshopper (Valanga nigricornis Burmeister), Cricket (Brachytrupes portentosus L.), and Mealworm (Tenebrio molitor) as Alternative Food Sources in Indonesia
}

\author{
Ivon Grace Paulin ${ }^{1}$, Maria Goretti M. Purwanto ${ }^{1} *$ \\ ${ }^{1}$ Faculty of Biotechnology, The University of Surabaya, Surabaya 60293, Indonesia \\ *Corresponding author: maria_gmp@staff.ubaya.ac.id
}

\section{ABSTRACT}

Insect is one of the alternative food sources which can be easily obtained and cultivated at a lower cost. Food sources must also provide daily nutrition; therefore, this study aims to compare the nutrition of edible insects in Indonesia, namely teak grasshopper (Valanga nigricornis Burmeister), cricket (Brachytrupes portentosus L.), and mealworm (Tenebrio molitor), with cork fish (Chana striata) that has been commonly consumed by the Indonesian people. The highest total protein content (Kjeldahl method) was found for fish (82.69\%), while the lower ones were found for grasshopper (72.50\%), cricket $(59.00 \%)$ and mealworm $(53.08 \%)$. This result was also in line with the total protein content found for fish $(11984.00 \mathrm{ppm}$ as the highest) and grasshopper (1016.33 ppm as the lowest). SDS-PAGE result also confirmed the highest protein content for fish where it showed the thickest band intensity for fish sample. Although cricket and mealworm were found to have lower total protein content (proximate assay), their fat and calorie levels were higher with calorie from fat values of $235.35 \mathrm{kcal} / 100 \mathrm{~g}$ for cricket and $195.93 \mathrm{kcal} / 100 \mathrm{~g}$ for mealworm. Proteolytic assay was carried out using papain to compare protein digestibility. The absorbance values from the proteolytic assay of cork fish and mealworm were higher than grasshopper and cricket, indicating that proteins of fish and mealworm were easier to hydrolyze. This could be explained so, that adult insects have a chitin structure that limits the hydrolysis process, or that papain might have a specific recognition sites and it fitted better to the fish and mealworm protein. Thus, each insect sample showed its characteristic nutritional profile and therefore, can be used as alternative food ingredient to meet the needs of protein and fat.

Keywords: Valanga nigricornis Burmeister, Brachytrupes portentosus L. Tenebrio molitor, Chana striata, Proximate Assay

\section{INTRODUCTION}

Entomophagy is a term of having insects as daily consumption like the consumption of meat, rice, and others and has traditionally been carried out by various countries in Asia, Africa, and South America [1]. The increase in food demand that occurs along with the growth of the population is not comparable with the land as a source of food sources, which triggers an increase in food prices, such as meat, eggs, soybeans, and other foods. Based on this, insect consumption can be used as an alternative source of meeting daily nutritional needs. Insects both in adult and larva stages have been consumed as an alternative source of protein by various countries, including Indonesia. Hymenoptera, 
Orthoptera, Hemiptera, and Isoptera species are commonly consumed in the adult stage while Lepidoptera, Coleoptera, and Diptera species are consumed in the larval stage [2].

Various edible insects in Indonesia, including cricket (Brachytrupes portentosus Lichtenstein), grasshopper (Valanga nigricornis Burmeister and Patanga succincta L.), dragonflies (Order Odonata, Pantala flavescent F. species), red palm weevils (Rhynchophorus ferrugineus F., Chalynchophorus F. Chalcosoma atlas L.), and bees (Xylocopa latipes Drury) are commonly consumed by rural communities in Java (East and Central) to Sumatra and Kalimantan [3], while edible insect larvae consumed by Papuans are sago larvae (Rhynochoporus bilineatus).

Other insects consumed by the Island of Java people are gangsir (Orthoptera: Brachytrupes portentosus L.) or known as cricket that has a dark brownish body and habitat in yards, rice fields, and plantations. These insects are also often considered as agricultural pests because of their habitat by digging holes and eating agricultural plants. They hunt these pests at once to be consumed as snacks. The nutritional content of Brachytrupes portentosus L. includes protein $48.69 \%$ and fat $20.60 \%$ [4]. Half a kilogram of fresh cricket costs from Rp. 30-40 thousand.

Mealworm (Coleoptera: Tenerbrio molitor) has been produced industrially in Europe since 2008 with a protein content of $24.3-27.6 \%$ in fresh mealworm, and has been increased to 50$75 \%$ with certain process of purifying the protein $[5,6]$. In the Biteback project by Mush'ab Nursantio and Ifdhol Syawkoni (Universitas Brawijaya, Indonesia), mealworm was used as an insect Bio-refinery, which is an alternative oil source to replace palm oil because of its high fat and oil content [7].

Teak grasshopper (Orthoptera: Valanga nigricornis Burmeister) live on teak trees (Tectona grandis) by eating teak leaves. Other habitats are found in rice fields. People in Banyuwangi and Purwoharjo usually hunt teak grasshopper in the rainy season for family consumption or as commodity, where the insect was previously processed into delicious and nutritious chips. The people of Mount Kidul, Yogyakarta province, sell fried and smoked grasshopper as a culinary specialty of the area. The price of smoked grasshopper is around $\mathrm{Rp}$ 45 thousand with a dry weight of 65 grams.

Cork fish (Perciformes: Chana striata) is a freshwater fish that has been cultivated in Indonesia, with the number reaching thousands of tons annually. As a source of protein that is commonly consumed and contains high albumin with thick and white meat texture, The market share for cork fish in Indonesia is increasing every year. People are now able to cultivate cork fis which was initially considered difficult to breed because of the cannibalistic. Cork fish sold and consumed directly as a food source of protein and as an extract supplement [8,9]. Studies on the composition of amino acids and the potential of cork fish protein as antioxidants and antidiabetic have been carried out. Protein content in flour is $66.08 \%$ and protein hydrolyzate from crude enzyme papain is $66.80 \%$ [10]. Because of the potential and nutritional value of cork fish are known, cork fish protein is used as a control protein compared to insect protein in this study.

Insects can be used as an alternative food source that is easily obtained in large quantities with effective and efficient cultivation that is in a fast period of time according to its metamorphosis and lower cost compared to other livestock. Therefore, this study aimed to find out the nutritional content (protein, fat, carbohydrate) of edible insects in Indonesia, namely grasshopper (Valanga nigricornis Burmeister), cricket (Brachytrupes portentosus L.), mealworm (Tenebrio molitor). The results were compared to cork fish (Chana striata) as a reference that is commonly consumed by the 
Indonesian people. As additional data, the results of the measurement of dissolved protein and SDS-PAGE are given in each sample.

\section{MATERIALS AND METHOD}

\section{Material}

Adult insects used were teak grasshopper (Valanga nigricornis Burm.), cricket (Brachytrupes portentosus L.), and mealworm (Tenebrio molitor), cork fish (Chana striata) was used as a reference sample that is commonly consumed by the Indonesian people. Wet fish samples were blended and dried in a $40^{\circ} \mathrm{C}$ temperature cabinet dryer for 7 days. Meanwhile, samples of grasshopper, cricket, and mealworm that have been dried in an intact condition were mashed first then dried again in a $40^{\circ} \mathrm{C}$ temperature cabinet dryer for 4 days. The dried sample was mashed and sieved 70 mesh into flour. Figure 1 shows the condition of the dried grasshopper, cricket, and mealworm samples in an intact condition.

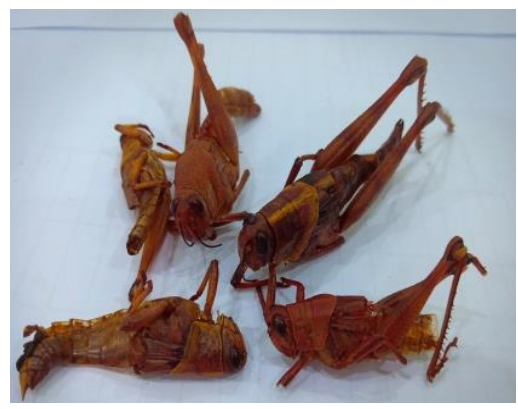

(a)

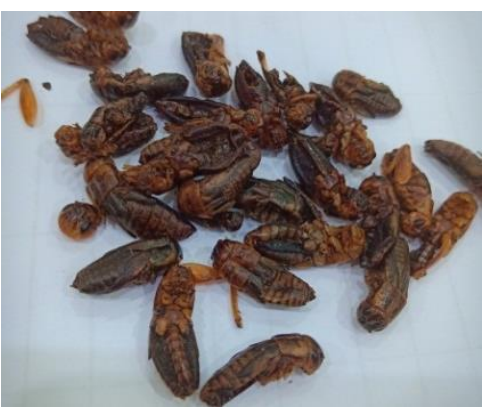

(b)

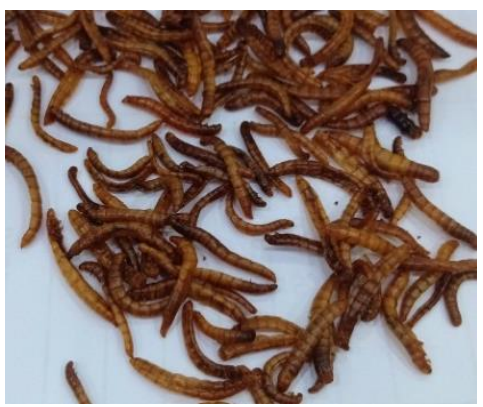

(c)

Figure 1. Dried (a) Grasshopper (Valanga nigricornis Burm.), (b) Cricket (Brachytrupes portentosus L.), and (c) Mealworm (Tenebrio molitor)

\section{Method}

Nutritional composition was determined by proximate assay, dissolved protein content was carried out by the Bradford method, while the profile of the dissolved protein was determined by the SDS-PAGE method and the protein digestability assay was carried out by the Casein Assay method.

\section{Color Measurement}

The sample flour was placed in a clear container and measured using a Minolta Spectrophotometer CR-20 (Konica Minolta, CR20). The screen display shows the measurement results in the form of $\mathrm{L}^{*}, \mathrm{a}^{*}, \mathrm{~b}^{*}$ or called the CIELAB color space. CIELAB is the most complete color space determined by the International Commission on Color Illumination (French Commission Internationale de l'eclairage, known as CIE) [11]. This color space is able to describe all colors that can be seen with the human eye. Converting $\mathrm{L}^{*}, \mathrm{a} *, \mathrm{~b} *$ values to HUE ( ${ }^{0} \mathrm{HUE}$ ) values can be done with the formula:

$$
\mathrm{HUE}=\tan -1\left(\mathrm{~b} * / \mathrm{a}^{*}\right)
$$

\section{Protein Extraction}

Protein extraction was carried out using the aqueous extraction method as used by Yi et al. [2], with little modification. The sample flour was dissolved in sterile deionized water with a concentration of $10 \% \mathrm{w} / \mathrm{v}(100 \mathrm{mg} / \mathrm{ml})$. The sample was homogeneous with vortex then centrifuged $10,000 \mathrm{rpm}$ for 10 minutes. The supernatant was inserted into the Amicon ${ }^{\circledR}-4$ $10 \mathrm{~K}$ centrifugal filter tube, then centrifuged at $4000 \mathrm{rpm}$ at $4^{\circ} \mathrm{C}$ for 15 minutes. A protein sample (the top of the tube) taken was put in Eppendorf $1.50 \mathrm{ml}$ and homogenized with vortex again. Protein extract samples were then ready to use. 


\section{Dissolved Protein Quantification}

The Bradford protocol was used to measure dissolved protein in water using Bradford reagents. Protein extracts were taken as much as $50 \mu \mathrm{l}$ and given Bradford reagents of $2.5 \mathrm{ml}$. The sample was incubated for 10 minutes and absorbance measurements were taken at $595 \mathrm{~nm}$. Standard curves were made using Bovine Serum Albumin (BSA) with a concentration range of 50-1000 ppm.

\section{Dissolved Protein Profile}

Sodium dodecyl sulfate-polyacrylamide gel electrophoresis (SDS-PAGE) was used to determine the molecular weight distribution fraction of sample proteins. The protein extract was pipetted as much as $100 \mu \mathrm{l}$ and sample buffer (1:1) was added in $1.50 \mathrm{ml}$ Eppendorf. Then, the mixture was heated for 5 minutes in boiling water. Samples were loaded in SDS PAGE gel containing $12.5 \%$ Bis/Tris acrylamide and running buffer Tris-Glycin. Molecular Weight Markers were used as a reference to measure the distance of protein migration.

\section{Protease Enzyme Preparation}

Papaya latex (Carica papaya) of 5 grams was added with 25 phosphate buffer $\mathrm{pH} 7.0 / 0.01 \mathrm{M}$, then added $25 \mathrm{mg} \mathrm{NaHSO}$ (as an antioxidant) and $25 \mathrm{mg} \mathrm{NaCl}$ (as an activator). The mixture was homogenized and incubated for 1 hour at $4^{\circ} \mathrm{C}$ while stirring. After 1 hour, the solution was cold centrifuged at 4,000 rpm for 15 minutes.
The supernatant was taken as a crude extract of the protease enzyme.

\section{Protein Digestibility Assay}

The determination of protein digestibility was done in vitro by an enzymatic method using a protease (papain) that was isolated from papaya and has been characterized for its enzyme activity. The insect and fish protein extract were pipetted $0.20 \mathrm{ml}$, given a $0.10 \mathrm{ml}$ protease enzyme and phosphate buffer $\mathrm{pH} 7.0 / 0.1 \mathrm{M}$ as much as $0.35 \mathrm{ml}$. The mixture was incubated at $65^{\circ} \mathrm{C}$ for 30 minutes; then the hydrolysis reaction was stopped by adding $0.25 \mathrm{ml}$ of Trichloroacetic Acid (TCA). The mixture was centrifuged at $6,000 \mathrm{rpm}$ for 5 minutes. The supernatant was measured at $275 \mathrm{~nm}$ using quartz cuvettes. A blank solution was made according to the sample, but the addition of the papain wass carried out after the addition of the TCA. The standard solution was made using tyrosine with a concentration range of 10-200 ppm.

\section{Proximate Assay}

Water content and ash content were determined using the Gravimetric method (SNI 01-28911992, points 5.1 and 6.1), total fat content was determined by soxhlet (SNI 01-2891-1992, point 8.2), and protein content was determined by the Kjeldahl method (SNI 01-2891 -1992, point 7.1).

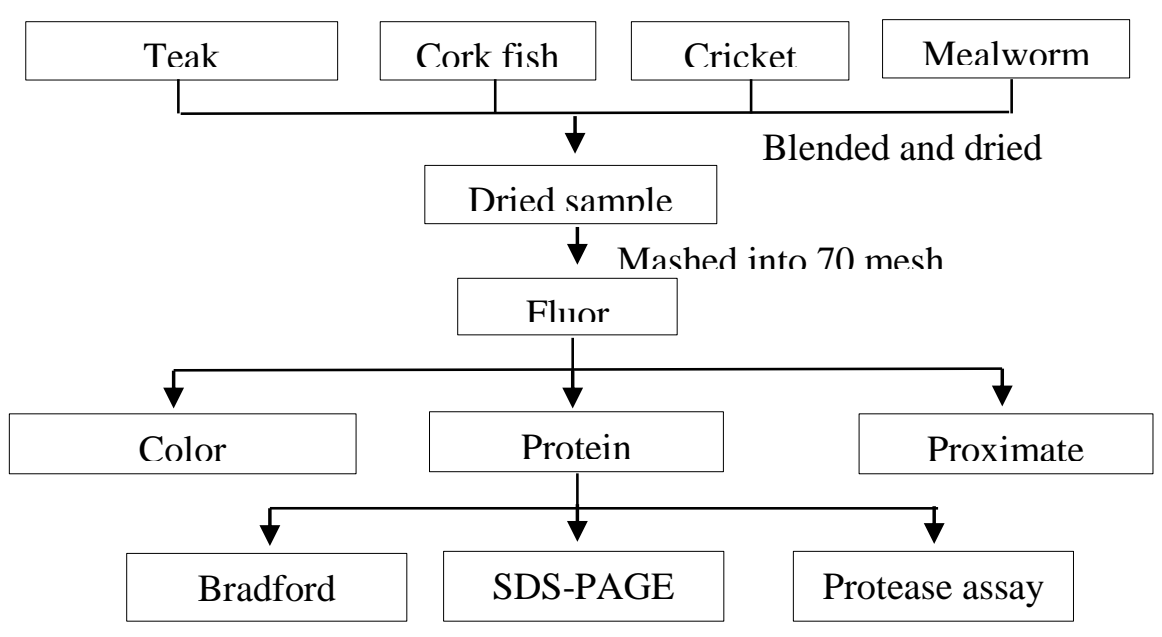

Figure 2. Flowchart of sample processing and analysis 


\section{RESULTS AND DISCUSSION}

\section{Flour Color and Aroma}

Table 1. Values of $\mathrm{L}^{*}, \mathrm{a}^{*}, \mathrm{~b}^{*}$ and ${ }^{0} \mathrm{Hue}$ as well as color range area

\begin{tabular}{cccccc}
\hline Sample & & \multicolumn{3}{c}{ Color reader test } \\
& L* & $*$ & $\mathbf{b}^{*}$ & ${ }^{\mathbf{0} H u e}$ & Color Dimension \\
\hline Grasshopper (Valanga nigricornis Burm.) & 53.70 & 7.73 & 18.07 & 66.84 & Yellow red \\
Cork Fish (Chana striata) & 75.10 & 2.77 & 18.43 & 81.45 & Yellow red \\
Cricket (Brachytrupes portentosus L.) & 50.73 & 5.60 & 10.40 & 61.69 & Yellow red \\
Mealworm (Tenebrio molitor) & 43.60 & 7.63 & 14.80 & 62.73 & Yellow red \\
\hline
\end{tabular}

The color of the protein flour is shown in Figure 3 , using a color reader, with the range of colors is shown in Table 1.

The color assessment system consists of three parameters, namely $\mathrm{L}^{*}, \mathrm{a}^{*}$, and $\mathrm{b}^{*}$. The CIE_L* dimension describes color brightness, 0 for black and 100 for white. The CIE_a* dimension describes the type of green-red color, where $\mathrm{a}^{*}$ negative indicates green and $\mathrm{a}^{*}$ positive indicates red. The CIE_b $*$ dimension describes blue-yellow, where $b^{*}$ negative indicates blue and $b^{*}$ positive indicates yellow [12]. Based on the calculation of the Hue degree, the sample has a reddish-yellow dimension. In plain view, grasshopper flour has a brownish color with the highest value of $a^{*}$ compared to other samples (more reddish), positive $b^{*}$ (yellowish). Fish flour has the brightest color so that the $\mathrm{L}^{*}$ value is highest compared to other samples and the lowest $a^{*}$ value (redness decreases) and the highest positive $b^{*}$ value, among others (yellow increases). Cricket flour has positive $a^{*}$ and $b^{*}$ values that combine yellow and red to brown. The mealworm flour has the lowest $\mathrm{L}^{*}$ value compared to other samples (darker), a high value of $\mathrm{a}^{*}$, after the grasshopper flour, indicates the sample's color is getting red. The mealworm flour smells like fermented shrimp paste, while the grasshopper flour smells milder but similar. The aroma of cricket was like cardboard paper and fish flour smells fishy as it does generally.

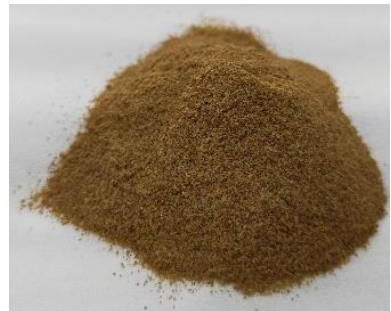

(a)

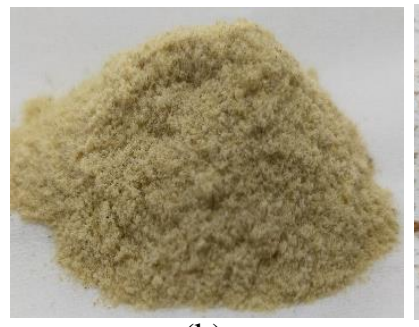

(b)

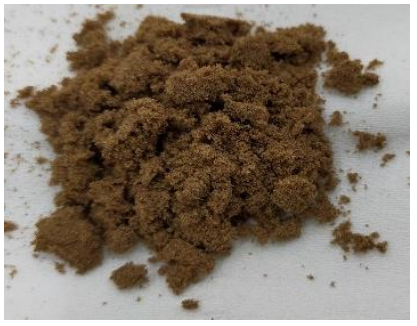

(c)

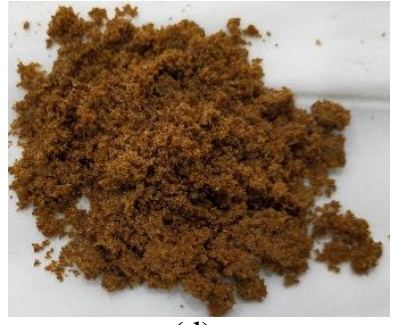

(d)

Figure 3. Flour of (a) grasshopper (Valanga nigricornis Burm.), (b) cork fish (Chana striata) (c) cricket (Brachytrupes portentosus L.), and (d) mealworm (Tenebrio molitor)

\section{Protein solubility}

Protein water solubility is depending on the characteristics of the sample type and the isoelectric point of the protein in a solution with a low or high $\mathrm{pH}$. Solubility can be influenced by a number of extrinsic and intrinsic factors. Extrinsic factors include $\mathrm{pH}$, ionic strength, temperature, and the presence of various solvent additives and intrinsic factor defined primarily by the amino acids. Increased negative surface charge correlates strongly with increased protein solubility and may be due to strong binding of water by the acidic amino acids [13]. Wellsoluble proteins are useful in many ways, especially for the formation of emulsions, foams, and gels in food designs [14]. 
Measurement result of the protein solubility in water using Bradford method is shown in Table 2 . The highest solubility of protein in awter pat $\mathrm{pH}=6.5$ was shown for fish, followed by grasshopper, mealworm, and finally cricket protein showe the loweet solubility. The low solubility of protein can be caused by the presence of fat and other contaminants that trap the protein, so in this case, the process of removing fat (defatting) can be done in order to get a purer protein. The condition for protein solubility is also supported by defatting protein hydrolyzate using additional solvents such as hexane or by supercritical carbon dioxide (SC$\mathrm{CO}_{2}$ ) $[5,15]$. Based on a study conducted by Sipponen et al. [15], the solubility of defatted cricket and mealworm after extraction with SC$\mathrm{CO}_{2}$ in neutral $\mathrm{pH}$ was increased to $20 \%$ and $16 \%$.

Table 2. Water soluble protein determination by Bradford method

\begin{tabular}{lc}
\hline \multicolumn{1}{c}{ Sample } & Protein (ppm) \\
\hline Grasshopper (Valanga nigricornis Burm.) & 1016.33 \\
Cork Fish (Chana striata) & 11984.00 \\
Cricket (Brachytrupes portentosus L.) & 563.00 \\
Mealworm (Tenebrio molitor) & 731.33 \\
\hline
\end{tabular}

Aqueous extraction was carried out at $\mathrm{pH}$ 6.5 without a defatting process that aims to observe how easily the protein can dissolve under normal conditions (without complex treatment), i.e., ordinary flour produced by drying, which aims to fortify food not only with protein, but with other substances as fat, mineral, and carbohydrate. Howevre, $\mathrm{pH}$ may influence the protein solubility. The highest solubility of T. Molitor protein was found at alkaline $\mathrm{pH} 11$ which was $97 \%$ and at $\mathrm{pH} \mathrm{2-3}$ which was 86$52 \%$ [14]. Protein solubility can also diminish along with a decrease in $\mathrm{pH}$ value to 3 and 4 in Orthoptera insects [16], this can be attributed to the conditions that increase the solubility of the insect protein occurs at alkaline $\mathrm{pH}$ like research conducted by Yi et al. [6]. Increased solubility is associated with the release of smaller peptide fragments, thereby increasing ionized groups (amino/carboxyl) that interact with water molecules and increase protein hydration. Insect protein solubility has similarities with data on solubility legumes, such as red bean flour [17] and Ginko Biloba [18].

In some research work, insect protein extraction is carried out using alkaline or enzymatic method to increase further the protein value and type of amino acid sample. The hydrolysis of proteins with enzymes increases the interaction between peptides and hydrogen bonds with water. Deionized water/aqueous extraction is done merely as an indicator of the interaction of non-hydrolyzed proteins with water (solubility of intact proteins) in the human body. The color of the supernatant after aqueous extraction is dark brown in mealworm (Tenebrio molitor) and cricket (Brachytrupes portentosus L.). Light brown in grasshopper (Valanga nigricornis Burm.) and bright yellow in fish (Chana striata).

\section{Proximate Assay}

The nutritional value of food plays an essential role in the health and fulfillment of daily human nutrition. The nutritional profile of samples is listed in Table 3. Proximate values were calculated from the dry weight of the sample. Protein content was analyzed through Kjeldahl method [15]. Based on the results of total protein measurements of the four samples, the highest protein of $82.69 \%$ is found for fish (Chana striata) and $72.50 \%$ for grasshopper (Valangan nugricornis Burm.). While the lowest protein of $53.08 \%$ was found for mealworm (Tenebrio molitor), and $59.00 \%$ for cricket (Brachytrupes portentosus L.) (Table 3).

However, mealworm flour has a higher fat content of $21.77 \%$ compared to fish and grasshopper, while cricket showed the highest fat content of $26.00 \%$. The highest calorie was found for cricket, which is $235.35 \%$ (Table 3 ). The protein, fat, and carbohydrate content found 
in mealworm species (Tenebrio molitor; Table 3) is similar to the results of the proximate analysis of Zielińska et al. [19]. While protein content in cricket (Brachytrupes portentosus L .; Table 2) has similarities with cricket species of Gryllus $s p$ as described in the Indonesian Journal of Forestry Research by Kuntadi et al. [20].

The highest protein solubility in fish and grasshopper (Table 2) might be correlated to a high total protein value and a lower fat content compared to cricket and mealworm. The trend was proportional to the total protein from proximate test results (Table 3). Cricket and mealworm have higher total fat, causing lower protein solubility, which are 563.00 and 731.33 ppm (Table 2). This can be due to the large size of protein particles trapped in larger fat structures and, thus, reducing their water solubility.

Table 3. Proximate test results in grasshopper (Valanga nigricornis Burm.); fish (Chana striata); cricket (Brachytrupes portentosus L.); and mealworm (Tenebrio molitor) samples

\begin{tabular}{ccrrr}
\hline Parameter & Grasshopper & Fish & Cricket & Mealworm \\
\hline Water content $(\%)$ & 7.05 & 7.63 & 4.22 & 4.86 \\
Ash $(\%)$ & 3.04 & 5.94 & 5.48 & 4.71 \\
Total Fat $(\%)$ & 9.45 & 3.00 & 26.15 & 21.77 \\
Total Protein $(\%)$ & 72.50 & 82.69 & 59.00 & 53.08 \\
Carbohydrate $(\%)$ & 7.96 & 0.74 & 5.15 & 15.58 \\
Calorie $(\mathrm{kcal} / 100 \mathrm{~g})$ & 406.89 & 360.72 & 491.95 & 470.57 \\
Calorie from fat $(\mathrm{kcal} / 100 \mathrm{~g})$ & 85.05 & 27.00 & 235.35 & 195.93 \\
\hline
\end{tabular}

Species, habitat, and insect feed may also affect the nutritional value of insects. Based on research by Rumpold and Schlüter [4], grasshopper and cricket in the Orthoptera order have higher protein and lower fat compared to mealworm in the Coleoptera order with lower protein and higher fat tendency. Adult insects also contain various constituents that add to the nutritional value of proteins such as chitin. In various studies presented by Gasco et al. [21], the content of chitin in insects provides resistance to disease because it increases the immune system of $\operatorname{IgG}$ and $\operatorname{IgA}$, and so does lauric acid in fatty acids against gram-positive bacteria. Based on this, insects can be used as nutritional intake as well as a healthy diet. A good diet recommendation is to have a lower carbohydrate content with high protein value. In this case, grasshopper and fish can be used for daily dietary nutrient intake with a high enough protein and lower carbohydrate compared to cricket and mealworm.

\section{Protein Digestability Assay}

In addition to having high amino acid content, the protein should be easily digested or enzymatically broken down by protease in the body so that the blood can circulates it for nutritional muscle needs, endurance, and other essensial metabolic purposes. Internal and external factors influence protein digestibility. The main internal factors are the amino acid composition of the protein and external factors are physical access related to compact cell structures and the presence of antinutrient compounds [22]. In this study, the parameter to seeing the ease of hydrolysis of proteins in insects and fish by papain was observed by using the absorbance of sample's hydrolysate at 275 $\mathrm{nm}$. Casein was used as a positive control for this assay to confirm the of enzyme (papain) activity to hydrolize protein substrate, which is indeicated by the release of tyrosine. Mon-Hyun et al. assessed the effect of different substrates on protease assay using different protein substrates such as casein, BSA, egg albumin, and gelatin and the highest protease activity was exhibited by casein [23]. That was the reason of the choice of casein as a positive conbrol.

In this case, papain can hydrolyze all flour sample but not equaly in each sample, namely insects, fish, cricket, and mealworm. Casein substrate as a control gave the highest absorbance followed by fish flour, indicating 
that more tyrosine was released due to the hydrolysis process. Melworm, cricket and grasshopper samples have neglectable absorbance values on the blank, indicating incomplete hydrolysis to amino acids, but could be still in the stage of becoming peptide protein. Grasshopper and cricket are adult insects which have chitin protein in the exoskeleton which can be a barrier for hydrolysis. Other reason might be related to the enzyme specificity towards recognition sites in each protein structure.
Papain is sulfhydryl protease which has a wide specificity. The specificity of cleavage of the X$\mathrm{Y}$ bond is: where $\mathrm{X}$ is a nonspecific amino acid, but arginine and lysine are preferred; and phenylalanine $\mathrm{X}-\mathrm{Y}$ bond where residues following phenylalanine are preferred; $\mathrm{Y}$ is a nonspecific amino acid residue [24]. In this case, hydrolysis by the papain may not be used as a single benchmark as a standard determining the digestibility of a protein material because each protease might have different recognition sites.

Table 4. Tyrosine Released by Protease Activity

\begin{tabular}{lcc}
\hline \multicolumn{1}{c}{ Sample } & $\begin{array}{c}\text { Absorbance of } \\
\text { Hydrolysate at 275 } \mathbf{~ n m}\end{array}$ & $\begin{array}{c}\text { Tyrosine in } \\
\text { Hydrolysate (ppm) }\end{array}$ \\
\hline Grasshopper (Valanga nigricornis Burm.) & 0 & 0 \\
Cork fish (Chana striata) & 0.736 & 102.24 \\
Cricket (Brachytrupes portentosus L.) & 0 & 0 \\
Mealworm (Tenebrio molitor) & 0.084 & 0 \\
Casein & 0.773 & 107.17 \\
\hline
\end{tabular}

\section{Protein MW Distribution with SDS-PAGE}

SDS-PAGE shows the dissolved protein distribution based on molecular weight (MW). The thickest band intensity was obtained from fish sample at sizes of 48-50 kDa, $35 \mathrm{kDa}$, and $25 \mathrm{kDa}$ (Figure 4, line 2a). Meanwhile, the grasshopper gave proteins of $35-25 \mathrm{kDa}$ (line 1a); cricket sample gave bands of $100 \mathrm{kDa}, 487$ $\mathrm{kDa}$ and under $25 \mathrm{kDa}$ (line 3a); while mealworm sample showed proteins under 25 $\mathrm{kDa}$ (line 4a). The research report from Sipponen et al. showed that cricket and mealworm insect proteins extracted with deionized water gave an average molecular weight below $25 \mathrm{kDa}$ and was not much different from extraction using $\mathrm{NaCl}$, which was also below $25 \mathrm{kDa}$ [15].

Overall, the profiling using SDS-PAGE showed that although the protein profile of each insects were initially different, they resulted in the same smaller protein/polypeptides after hydrolysis assay with papain, appeared at around 23-25 kDa was found for hydrolysate of grasshopper, fish, cricket, and mealworm samples. Only for fish sample, the band at about $23 \mathrm{kDa}$ was much weaker than that of other samples, presummably because the fish proteins were easier hydrolyzed to even smaller peptides.
This made the protein stacked at the baseline of the gell.

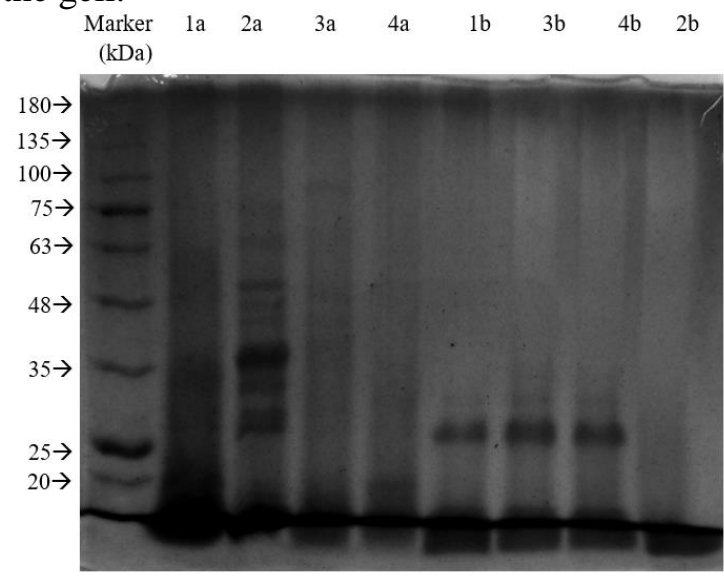

Figure 4. Protein profilling with SDS-PAGE M: molecular weight marker;

1a: grasshopper water soluble protein; 2a: fish water soluble protein;

3a: cricket water soluble protein; 4a: mealworm water soluble protein;

1b: grasshopper supernantant after hydrolysis by papain (digestability assay);

2b: fish supernantant after hydrolysis by papain (digestability assay);

3b: cricket supernantant after hydrolysis by papain (digestability assay);

4b: mealworm supernantant after hydrolysis by papain (digestability assay). 


\section{CONCLUSION}

Based on the results of proximate assay, the nutritional profiles of fish flour and insect flours were not much different. Grasshopper (Valanga nigricornis Burmeister) flour showed high protein content. While cricket insects (Brachytrupes portentosus L.) and mealworm (Tenebrio molitor) showed caloric and fat values that are superior to cork fish (Chana striata). Therefore, insects can be used as an alternative nutritious food source at a affordable price. Based on Bradford assay, fish and grasshopper protein can dissolve better in water compared to cricket and mealworm do. However, protein of adult insects such as grasshopper and cricket are also challenging to hydrolyze because they have the structure of chitin. Regarding protein digestibility, all three samples from grasshopper, cricket, and mealworm were easily digested/hydrolized by papain, while fish protein showed the highest digestibility. The author also suggests a protein digestibility assay using various enzymes with multiple recognition sites to be carried out in the future, rather on rely only on papain. The enzymes used can also be isolated from human digestive system to determine protein digestibility or to obtaine protein hydolyzate.

\section{ACKNOWLEDGEMENTS}

The study was conducted at the Laboratory of Purification and Molecular Biology of The University of Surabaya Faculty of Biotechnology.

\section{REFERENCES}

[1] Rumpold, B.A., Schlüter, O., 2015. Insectbased Protein Sources and Their Potential for Human Consumption: Nutritional Composition and Processing. Anim Front, 10.2527/af.2015-0015.

[2] Yi, L., Lakemond, C.M., Sagis, L.M., Eisner-Schadler, V., Van Huis, A., Van Boekel, M.A., 2013. Extraction and Characterisation of Protein Fractions from Five Insect Species. Food Chemistry, 141: 3341-3348.

[3] Lukiwati, D. R., 2010. Teak Caterpillars and Other Edible Insects in Java. Food and
Agriculture Organization of the United Nations. Forest Insects as Food: humans bite back, 99.

[4] Rumpold, B.A., Schlüter, O.K., 2013. Nutritional Composition and Safety Aspects of Edible Insects. Mol. Nutr. Food Res, 57: 802-823.

[5] Bußler, S., Rumpold, B., Elisabeth, J., Rawel H., Schlüter, O., 2016. Recovery and Techno-functionality of Flours and Proteins from Two Edible Insect Species: Mealworm (Tenebrio molitor) and Black Soldier Fly (Hermetia illucens) Larvae. Heliyon Elsevier Ltd, 2405-8440, e00218.

[6] Yi, L., Van Boekel M.A.J.S., Lakemond C.M.M., 2017. Extracting Tenebrio molitor Protein While Preventing Browning: Effect oh $\mathrm{pH}$ and $\mathrm{NaCl}$ on Protein Yield. Journal of Insects as Food and Feed, 3 (1): 21-31.

[7] Nursanto M., Syawkoni I., 2017. Insect Bio-refinery. Universitas Brawijaya Malang, Indonesia. [online] http://www. bitebackinsect.com/ Diakses 27 Januari 2020.

[8] Infoakuakultur. 2019. Budidaya Ikan Gabus Tetap Menguntungkan [online] https://www.minapoli.com/info/budidayaikan-gabus-tetap-menguntungkan. Diakses 14 Juli 2020

[9] Wiguna, I., Titisari, A., Sari, I., Ramadhan, M., Febriansyah, R., Admina, 2016. Pasar Bagus Gabus Ternak. http://www.trubusonlineshop.com/berita/2 016-09-06/44/Pasar-Bagus-Gabus-

Ternak.html. Diakses 14 Juli 2020

[10] Prastari, C., Yasni, S., Nurilama, M., 2017. Karakteristik Protein Ikan Gabus yang Berpotensi Sebagai Antihiperglikemik. JPHPI. Volume 20, nomor 2.

[11] Rulaningtyas, R., Suksmonon, A.B., Mengko, T., Saptawati, P., 2015. Segmentasi Citra Berwarna dengan Menggunakan Metode Clustering Berbasis Patch untuk Identifikasi Mycobacterium tuberculosis. Jurnal Biosains, 17 (1).

[12] Hunterlab. 2012. Measuring Color using Hunter L, a, b versus CIE 1976 L*a*b*. Hunter Associates Laboratory Inc.

[13] Kramer, R., Shende, V., Motl, N., Pace, C. N., Scholtz, J. M., 2012. Toward a 
Molecular Understanding of Protein Solubility: Increased Negative Surface Charge Correlates with Increased Solubility. Biophysical Journal. Volume 102, pp 1907-1915.

[14] Zielińska, E., Karas, M., Baraniak, B., 2018. Comparison of Functional Properties of Edible Insects and Protein Preparations thereof. Food of Science and Technology, 91: 168-174.

[15] Sipponen, M., Mäkinen, O., Rommi, K., Heiniö, R.L., Mantila, U.H., Hokkanen, S., Hakala, T.K., Nordlund, E., 2017. Biochemical and Sensory Characteristics of the Cricket and Mealworm Fractions from Supercritical Carbon Dioxide Extraction and Air Classification. Eur Food Res Technol, 10.1007/s00217-0172931-1.

[16] Chatsuwan, N., Nalinanon, S., Puechkamut, Y., Lamsal, B., Pinsirodom, P., 2018. Characteristics, Functional Properties, and Antioxidant Activities of Water-Soluble Proteins Extracted from Grasshoppers, Patanga succincta and Chondracris roseapbrunner. Hindawi Journal of Chemistry, 6528312.

[17] Wani, I.A., Wani, A., Sogi, D., Gill, B.S. 2013. Physico-chemical and Functional Properties of Flours from Indian Kidney Bean (Phaseolus vulgaris L.) Cultivars. LWT Food Science and Technology, 53(1): 278-284.
[18] Deng, Q., Wang, L., Wei, F., Xie, B., Huang, F., Huang, W., 2011. Functional Properties Of Protein Isolates, Globulin and Albumin Extracted from Ginkgo Biloba Seeds. Food Chemistry, 124(4): 1458-1465.

[19] Zielińska, E., Baraniak, B., Karaś, M., Rybczyńska, K., Jakubczyk, A., 2015. Selected Species of Edible Insects as a Source of Nutrient Composition. Food Research International, 77: 460-466.

[20] Kuntadi, Adalina, Y., Maharani, K.E., 2018. Nutritional Compositions of Six Edible Insects in Java. Indonesian Journal of Forestry Research, 5 (1).

[21] Gasco, L., Finke, M., Huis, A.V., 2018. Can Diets Containing Insects Promote Animal Health? Journal of Insects Ad Food and Feed, 4 (1): 1-4.

[22] Joye, I., 2019. Protein Digestibility of Cereal Products. Journal of Foods, 8: 199, dio: 10.3390/foods8060199.

[23] Mon-Hyun, P., Buddhi, C. W., Min-Ho, Y., 2013. Purification and Characterization of Protease Enzyme from Burkholderia stabilis. African Journal of Biotechnology. Volume 12(12), pp 1408-1418

[24] Mótyán, J.A., Tóth, F., Tőzsér, J. 2013. Review: Research Application of Proteolytic Enzymes in Molecular Biology. Biomolecules, 3: 923-942. 